\title{
Symbolic Communication of Tourism Images in Soap Opera Televisons
}

\author{
http://dx.doi.org/10.25008/jkiski.v6i2.604
}

\section{Gusti Agung Alit Suryawati ${ }^{1^{*}}$}

\author{
${ }^{1}$ Department of Communication, Universitas Udayana \\ J1. Jend. Sudirman, Kota Denpasar 80361, Bali - Indonesia \\ *Corresponding author: igaalitsuryawati@unud.ac.id
}

Submitted: June 21, 2021, Revised: September 22, 2021, Accepted: October 13, 2021

Accredited by Kemristekdikti No. 28/E/KPT/2019

\begin{abstract}
Tourism in Bali is growing so rapidly that it continues to increase every year. The increasing number of foreign and domestic tourist arrivals leads to an increase in domestic services and promotions. Arief Yahya assessed that film had become a useful medium and contributed greatly to promoting Indonesian tourism. The aim of this research is to know how soap opera and film could be used as a means of promotion to know about Tourism in Bali and other state problems: (1) How Broadcasting as a mass communication activity functions as a medium of information, education, entertainment, health, control and social control; (2) How to carry out the function of soap opera and film as a means of promoting Tourism in Bali; (3), How broadcasting also has economic and cultural functions. Theory and Method: Symbolic Theory and Method use perception and qualitative analysis which explore by watching the eat, pray, and love films and some soap operas whose shooting take place in Bali. They can serve as a reference for the industrial world to make films that can inspire audiences to come to the place or location of the film, and also a reference for tourists who would come to Bali.
\end{abstract}

Keywords: Tourism images; promoting; reference; soap opera television; symbolic theory.

\section{Introduction}

Soap operas and films as part of the creative industry that continues to develop dynamically (Berto, 2018). The surge in the development of sinetron (soap opera) and film productions today is related to the high demand to meet the market, especially domestic entertainment media broadcast on television. As part of television broadcast programs, soap operas and films have an effect on their viewers. In addition to news media, television broadcasts information and entertainment in the form of soap operas and films. The existence of television stations has played a role as a means of non-formal public education, although its reach is very broad beyond formal education (Sujarwa, 2010: 29).

Television is one form of mass media which in addition to having a strong appeal due to the elements of words, music and sound effects, also has another advantage, namely the visual element in the form of moving images that can create a deep impression for the viewer. In an effort to influence audiences by evoking the emotions and thoughts of viewers, television has more prominent abilities than other mass media (Atmowiloto, 1996: 6).

Today, television has become an agent that markets popular culture. Popular culture as communication, clearly describes how culture is consumed and created by producers to fulfill the wishes of the audience (Subandi, 2007; Komalawati, 2020). Mass culture or pop culture is created on a large scale to cause cultural banalization. The symbolic communication conveyed has built communication through culture. As an agent of culture, television has succeeded in shaping the human soul. 
Popular culture, including soap operas and films that adorn the mass media today, has both positive and negative influences. The positive influences of the mass media are, among others, to provide information about various events, in addition to a. knowledge of human life, technological developments, cultural traditions and tourism potential in various parts of the world. On the other hand, mass media also has negative influences, including encouraging consumptive and imitative behavior, and even being able to stimulate violent and anti-social behavior for its viewers (Bungin, 2006: 236). For this reason, the development of soap operas and films must be in line with Law No. 32/2002 concerning Broadcasting. In essence, this policy is a regulation so that television media is able to carry out its function as a healthy medium of information, education, and entertainment. In addition, television is also expected to be a medium that has the function of control and social glue (Article 4, Law No. 32/2002).

The aim of this research is to know how soap operas and films could be used as promotion tools to know about Tourism in Bali and other state problems including: (1) How Broadcasting as a mass communication activity functions as a medium of information, education, entertainment, health, control and social control; (2) How to carry out the functions of soap operas and films as referred to above as a means of promotion to attract tourists to come to Bali and others (1), How broadcasting also has economic and cultural functions.

\section{Theoretical Framework}

To understand the response of the audience of soap operas and films studied, the theory of symbolic interactionism is applied. The basic character of the theory of symbolic interactionism is the relationship that occurs naturally between humans in society and society with individuals. Interactions between individuals develop through the symbols they create. These symbols include gestures, among others; voice or vowel, physical movement, body expression or body language, which is done consciously. This is called symbol (Arisandi, 2014).

The essence of symbolic interactionism theory is that human interaction with each other is influenced by certain symbols (Riyadi, 2001; Amrihani \& Ritonga, 2021), including the content of dialogues, scenes in soap operas and films that are shown so that they can influence the thoughts and actions of the audience. The thoughts and language of soap operas and films can be understood by the audience.

\section{Material and Methodology}

Among the themes of soap operas and films broadcast by various television stations in the country are shows related to the traditions of local communities and the tourism potential of the archipelago. In connection with this topic, this paper deliberately examines the problems of tradition and the potential of Indonesian tourism contained in soap operas, namely the soap operas "Arti Sahabat" and "Kadek Made in Bali" as well as film shows on the big screen, namely the film "Laskar Pelangi", "Love from Wamena", and "Eat Pray Love". The main issues highlighted include the following three points. First, what are the impressions presented to the audience from the soap operas and films? Second, how is the tendency of viewers to respond to these soap operas and films? It is hoped that this study has theoretical benefits, namely as part of efforts to develop the repertoire of knowledge related to national culture and tourism, and its practical benefits are to strengthen the nation's cultural identity through soap operas and films.

\section{Result and Discussion}

Mass media, especially television, presents various kinds of arts, including films, music, modern and traditional arts. One type of entertainment that continues to grow and gets rave reviews from television audiences is electronic cinema (sinetron). Almost all television stations, both TVRI and national and local private television stations broadcast soap operas running from morning to night. Sinetron is a serial television series and consists of several episodes. The number of episodes that are aired depends on the response from consumers.

Television companies will broadcast soap operas that sell well in the market. The show will be stopped when it no longer has a place in the hearts of its viewers. Soap opera consumers are also broad because the audience includes all elements of society, including the audience of youth groups. The existence of soap operas as a cultural product is able to position itself as one of the entertainment programs in increasingly sophisticated technology. Through soap operas, Indonesian people have become loyal consumers to follow soap operas and are hegemonized by various forms of thought, 
lifestyle, lifestyle, and even outlook on life (Sujarwa, 2010: 27).

Soap operas have an influence on the audience. Through advertisements, soap operas, films, TV broadcasts, they present branding (imaging) of a particular tourist object or area. Filming locations, stories and local culture (traditions) can be constructed in such a way that the audience has a perception of what they see. Among the soap operas that have visited television viewers in Indonesia are the youth soap opera "Arti Sahabat" which was broadcast by Indosiar television station in 2010 and 2011, and the soap opera "Kadek Made in Bali" which was broadcast by RCTI in 2010.

First, the soap opera "Arti Sahabat" which was screened by Indosiar in 2010 and 2011 is one of the teen drama genre soap operas. The soap opera "Arti Sahabat" outlines the story of urban youth associations. In this teen soap opera, there is a scene with the background of Borobudur Temple. Here at a glance the soap opera "Arti Sahabat" wants to introduce to the public about a tourist attraction in Central Java, namely Barobudur Temple. However, it turns out that the background of Borobudur Temple in this teen soap opera is only used as decoration or fragments that are separated from the context of the story as a whole.

Second, the soap opera "Kadek Made in Bali" which was aired on RCTI in 2010. This drama genre soap opera reveals the reality of night life, the glittering world (clubbing) in the center of Bali's tourism as well as rural life and the potential for natural tourism around the Amed coast, in Karangasem district. The soap opera "Kadek Made in Bali" also tells the story of a meeting between a beautiful teacher (Kadek) as a village girl who never gives up. Although he is an elementary school teacher in his village, he is willing to become a manual

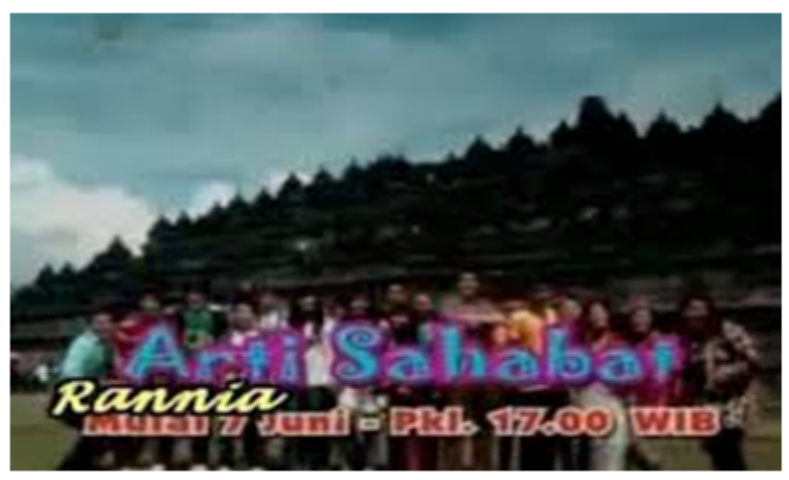

Figure 1. Soap Opera Arti Sahabat

When comparing the correlation between the teenage soap operas "Arti Sahabat" and "Kadek Made in Bali", the soap opera "Arti

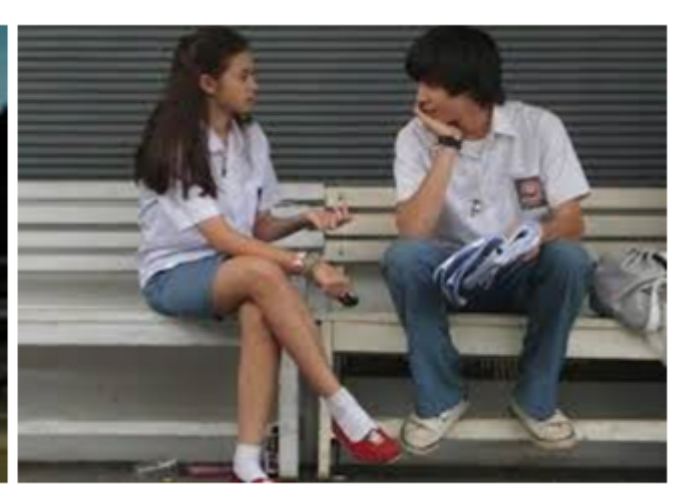

worker (truck driver) to realize his ambition, building a library at his school.

The figure of Kadek symbolizes the figure of a hard-working Balinese woman who does not want to give up on the situation. A figure who cares about education problems in his village. This is indicated by his status as an elementary school teacher who wants to build a school library. While he was willing to become a truck driver and struggle to build a school library, Kadek met Made Nico (a young Balinese who has lived in Australia) who was looking for a beach to go surfing. Made's motorbike fell into a ravine because it grazed Mrs. Kadek's truck. It was this small incident that brought Kadek and Made together, and they eventually became lovers.

Soap operas that are screened on television have the potential to affect their audience. Mass media communicators often perform various actions in the construction of reality where the end result has a strong influence on the formation of meaning or image about a reality. The media also play a special role in influencing or sustaining a particular culture through the information it produces.

Viewers will capture the show, including the plot and setting of the filming location that frames the soap opera. Setting of place is matters related to geographical problems, time setting is related to historical problems, and social setting is related to social life. Setting includes a description of a geographical location, including topography, scenery, to the details of the equipment of a work room or the daily activities of the characters; the time of the occurrence of the incident, the historical period, the season of occurrence, the religious, moral, intellectual, social, and emotional environment of the character (Sugihastuti, 2005:54).

Sahabat" only briefly reveals one of the tourist destinations in Central Java, namely Borobudur Temple, while the soap opera "Kadek Made in 
Bali" manages to reveal the reality of the life of tourism in Bali, namely the life of the glittering world (clubbing) in the tourism center of Kuta and the natural tourism potential of Amed Beach, Karangasem. The sinetron, whose script was written by Faldin Martha, aired on RCTI in
2010 and even managed to reveal a portrait of the life of a tenacious Balinese woman who still adheres to traditions in her hometown (the figure of a Kadek) and a modern Balinese youth (Made Nico has settled in Australia) who are enjoying their vacation in Bali.
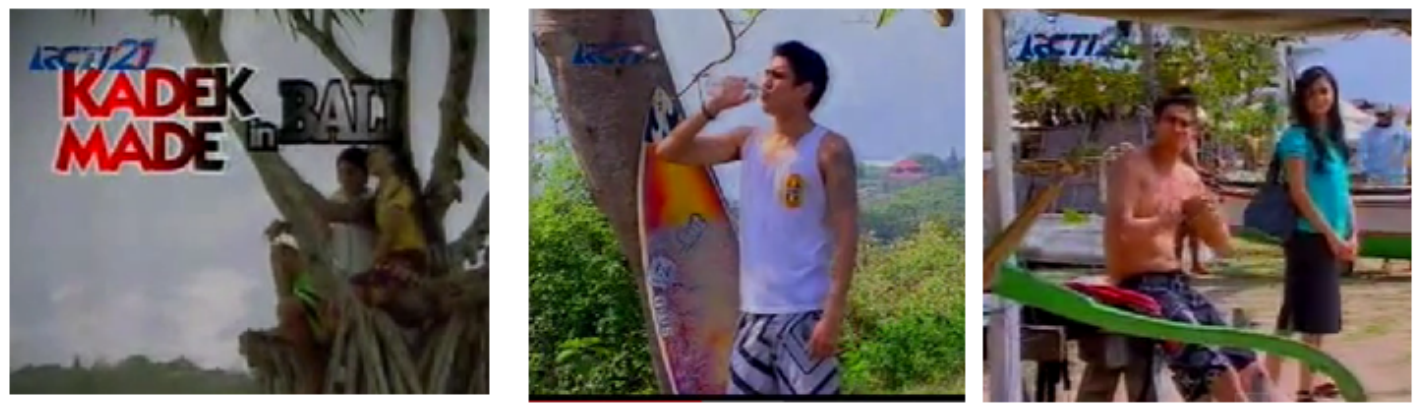

Figure 2. Kadek Made in Bali

Imagery of tourism objects in the films Laskar Pelangi, Love from Wamena and Eat Pray Love

Apart from using soap operas, the imaging of Indonesian tourism objects can also be done through film media. If in soap operas, the background story appears to be fragmented (according to the series of soap operas that are continued), then the background story in a film feels more complete with a fairly long run time (1.5 - 2 hours). Some interesting films to watch are the educational film "Laskar Pelangi", the drama film "Eat Pray Love" and the drama film "Cinta dari Wamena".

First, the film "Laskar Pelangi" which was hit in 2008 succeeded in introducing the
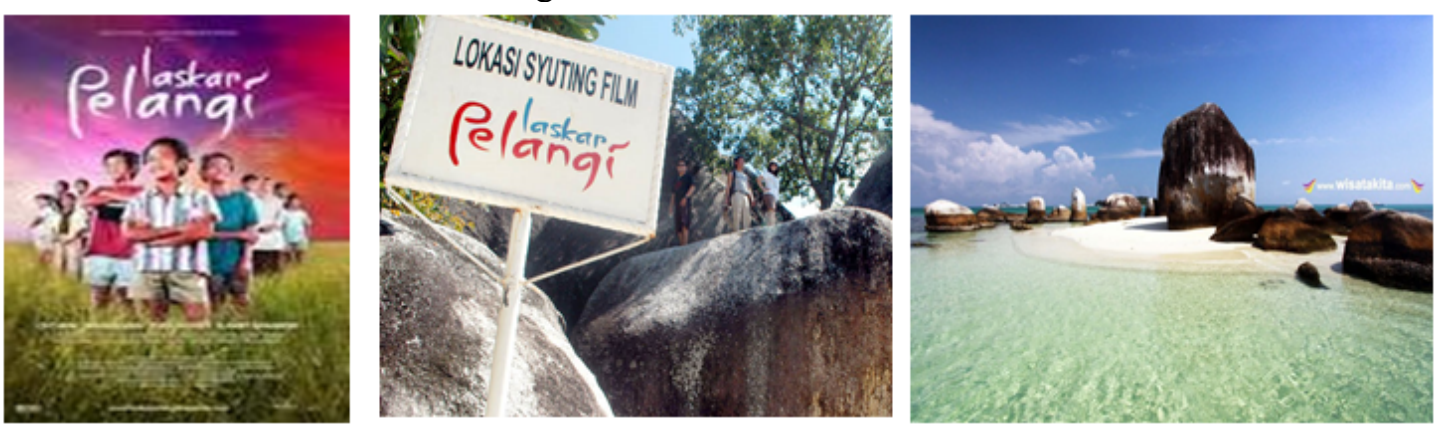

Figure 3. Laskar Pelangi tourist destinations of Belitung Island. Laskar Pelangi (2008) is a film adaptation of the book Laskar Pelangi written by Andrea Hirata. Educational films have been watched by more than 4.6 million people. In general, films (which are also packaged in a number of soap operas on a national private TV) show stories of education and simplicity. The screenwriter and director of Laskar Pelangi have been able to convey the message of the importance of upholding moral values in the education of the next generation. In addition, the film "Laskar Pelangi" also had an impact on strengthening the branding of Belitung Island tourism objects and making it one of the attractive tourist destinations.
The shooting location for the film Laskar Pelangi is Belitung Island, Belitung Regency, Bangka Belitung Islands Province. In recent years Belitung Island has become increasingly famous as a tourist destination after the Laskar Pelangi film, which was edited on a local island. Belitung Island used to be known as a tin island and is one of the richest islands in Indonesia, but since the film Laskar Pelangi was made, now the island is known as the Laskar Pelangi Island which is very beautiful and unique. There are many large mountain rocks on the beach which are also white sand that makes us amazed by the beauty of this island. There is a Belitung Island package 4 days 3 nights with tourist activities: (1) swimming, snorkeling, (2) playing cards, getting to know, (3) seeing the life of the people of Belitung Island, (4) seeing the coral reefs / marine life of the Island of Belitung, (5) traveling around the islands in Belitung hunting for photos with friends, sunrise and sunset, (6) 
visiting places where the rainbow army was shooting, (7) visiting the city of Manggar (city of 1001 coffee shops).

Second, the film "Cinta dari Wamena" (2013) which has a drama genre. The film, directed by Lasja F. Susatyo, tells the story of friendship and love, set against the backdrop of teenage life and the beautiful nature of Papua. The film, which has been screened in Indonesian cinemas in 2013, is played by Benjamin Lagowan, Amyra Jessica, Nicholas Saputra, Susan Bachtiar, Maximus Itlay, Madonna Marey.

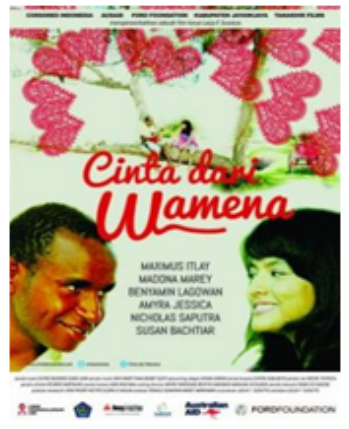

Judging from its mission, the film "Cinta dari Wamena" is part of a movement that responds to the problem of HIV and AIDS which has become a serious social-health problem in Papua. It is said that Litius, Tembi and Martha are three friends who live in a small town in Papua. They have a dream to be able to continue in school. This dream brought them to Wamena, where they could go to school for free. But there, their friendship and dreams are tested by a permissive lifestyle, and the AIDS epidemic that plagues Papuan youth. Their life journey also takes them to different directions and places, from Papua to Jakarta, where meeting a musician makes Litius look for a lost friendship again.

Third, the film "Eat Pray Love" - one of which was shot in the tourist destination of Ubud. "Eat Pray Love" is a 2010 American drama film based on the novel "Eat, Pray, Love" by Elizabeth Gilbert. Filming for this film began in August 2009. The shooting

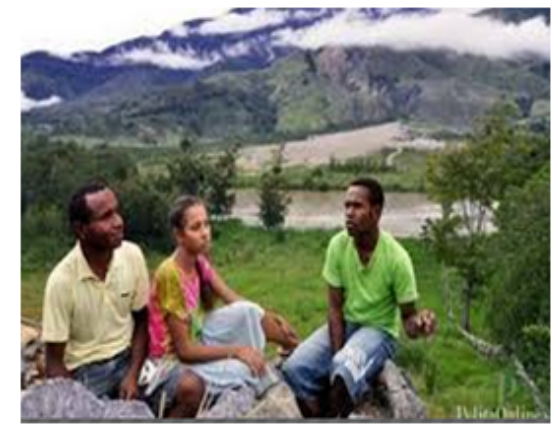

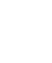


The stories of the two soap operas and three film stories above, directly or indirectly, have succeeded in revealing the realities of life, traditions and some of the interesting tourist objects of the archipelago. Of course there are still many objects or other tourism potentials of the archipelago that have not been explored to be introduced to the public, both the public at home and abroad. Indonesia has so many tourist attractions, namely the exotic cultural traditions of the local community and stunning natural scenery. Only a small number of objects or tourist destinations in the archipelago have been excavated.

By using several eclectic theories, namely the theory of media influence and framing theory, soap operas and films depict the following. First, soap operas and films can be used as media to make an inventory and get to know local traditions, Indonesian culture, and Indonesian tourist attractions. Soap operas and films have served as effective tourism promotion media. A glimpse of the background of Borobudur Temple in the soap opera "Arti Sahabat" has awakened the audience's memory of the existence of the Borobudur tourist destination in Central Java.

Furthermore, the soap opera "Kadek Made in Bali" has succeeded in revealing a glimpse of the life of the Balinese tourism community and the natural panorama of the Amed Coastal countryside in Karangasem Regency. Likewise the film "Laskar Pelangi" which managed to introduce quite intensely the life of the people of Belitung Island and the fascinating natural tourism potential in the local area. After the creation of the film "Laskar Pelangi", the natural tourist destination of Belitung Island has become increasingly famous as one of the tourist attractions that continues to grow. This also applies to the film "Cinta dari Wamena" which has succeeded in inviting audiences to empathize with the issue of HIV and AIDS. In addition, directly or indirectly, this film, which was made in Eastern Indonesia, has succeeded in describing the natural beauty of the virgin land of Papua. Finally, the film "Eat Pray Love" starring the famous artist Julia Robert was also able to attract the attention of the audience. Some of the background stories exploit the natural beauty around Ubud, which is able to attract the attention of viewers to get to know the tourist destinations of Ubud, Bali. The film "Eat Pray Love" can strengthen the branding of the island of the gods of Bali as a "paradise on earth" that is dreamed of by tourists, both domestic and foreign tourists. The existence of "world-class" film shows such as "Eat Pray Love" is certainly a very effective promotional medium in introducing the nation's culture and the tourism potential of the archipelago. The world community is becoming more familiar with the exotic power of the island of the gods as a famous tourist destination so far.

Second, the soap operas and films above can also strengthen the identity and ethnicity of local culture as well as become a mirror of the cultural identity of the nation. The beauty of nature and the diversity of local cultural traditions are woven into the cultural mosaic of this plural and beautiful archipelago. The diversity of traditions and local identities is able to strengthen the identity politics of an ethnic group who are members of the archipelago community based on Bhineka Tunggal Ika. For local people, soap operas and films are expressions of local ethnic identity situations. This awareness of ethnic identity becomes even stronger when it becomes the basis for the struggle for group aspirations (bagir, 2011: 18). Identity is not only a socio-psychological issue but also a political one. Identity which is one of the basic concepts of citizenship (citizenship) is the awareness of human equality as citizens. This identity as a citizen becomes a political frame for everyone, regardless of any other identities they have such as religious, ethnic, regional and other identities (Bagir, 2011: 17).

Third, the creative industries of the two soap operas and three films have supported the empowerment of local communities in the development of sustainable tourism. This is shown, among other things, by the packaging of tour packages after the presence of the film "Laskar Pelangi" in Belitung Island tourist destinations and the tour package Julia Robert's bicycle trail in Ubud. This fact is in accordance with the behavioristic theory that learning is the result of the interaction between stimulus and response (Slavin, 2000:143). Local tourism actors have learned and deliberately exploited the local natural potential into attractive natural tourism packages. Cycling tour packages across the Julia Robert trail in Ubud have been warmly welcomed by domestic and foreign tourists.

Fourth, all of the above-mentioned soap operas and films also encourage viewers to get to know the cultural traditions of the archipelago and raise awareness of the importance of preserving the beauty of nature. Viewers of soap operas and films are invited to 
be in harmony with nature and to preserve the environment in order to realize sustainable tourism. According to Ardika (in Prasiasa, 2013: 160), sustainable tourism has pillars of quality, continuity, and balance that harmonizes the needs of local communities, preservation of resources (physical and cultural) and tourist satisfaction.

As a creative industry, soap operas and films with ethnic themes and introducing Indonesian nature are still limited and have the potential to be developed. The presence of soap operas that raise the potential of traditions and natural tourist destinations can be an educational venue as well as effective tourism promotion. Evidently, the film "Laskar Pelangi" has been able to attract tourists to Belitung Island, the film "Cinta dari Wamena" has inspired viewers to travel to the Land of Papua, as well as the film "Eat Pray Love" which has succeeded in establishing Ubud which has a world-class tourist magnet that is dreamed of tourists to visit it, both domestic and foreign tourists. Producers need to pay more attention to that the attractiveness of tradition and the natural beauty of the archipelago can be further "empowered" as the theme of soap operas and films to support the development of the tourism industry in Indonesia.

\section{Conclusions}

The background of soap operas and films that reveal the tradition or potential of a tourist attraction in an area can strengthen the image of the archipelago tourism in question. The image of tradition and tourism potential in an area can also be an attraction for the object or tourist destination in question, including what has happened in the tourist destinations of Belitung Island, Tanah Papua and Ubud, Bali. The development of the Creative Industry, one of which is film can increase the economy that can increase the GDP of a region.

\section{References}

Amrihani, H., \& Ritonga, R. (2021). Social Media Literacy Counseling for Prospective Propagators to Thwart Hoax Information. Iccd, 3(1), 192-195. https://doi.org/10.33068/iccd.Vol3.Iss1.3 $\underline{36}$.

Amrihani, H. (2021). Retorika Deliberative: Komunikasi Marah Marah Pejabat di Ruang Publik. Jurnal Pewarta Indonesia, $3(2)$, 124-131. doi:https://doi.org/10.25008/jpi.v3i2.87.
Atmowiloto, A. (1996). Telaah Tentang Televisi. Jakarta: Gramedia.

Arisanti, H. (2014). Buku Pintar Pemikiran Tokoh-Tokoh Sosiologi Dari Klasik Sampai Modern. Jakarta: IRCiSoD.

Bagir, Z.A. (2011). Pluralisme Kewargaan, Arah Baru Politik Keragaman di Indonesia. Bandung: Yogyakarta.

Baran, S.J. (2002). Introduction to Mass Communication: Media Leteracy and Culture $2^{\text {nd }}$. New York: McGraw Hill.

Berto, A. (2018). The Capitalization of Backpacking Tourism Culture in Indonesian Films. Jurnal Komunikasi Ikatan Sarjana Komunikasi Indonesia, $3(1)$, $1-11$. doi:https://doi.org/10.25008/jkiski.v3il. $\underline{143}$

Bungin, B. (2006). Sosiologi Komunikasi. Jakarta: Prenada Media Group.

Eriyanto. (2002). Analsis framing. Yogyakarta: LkiS.

Komalawati, E. (2020). Teen and Social Violence in Cinema: Construction of Teen Identity in Film Dilan 1990. Jurnal Komunikasi Ikatan Sarjana Komunikasi Indonesia, 5(2), 225-231. doi:https://doi.org/10.25008/jkiski.v5i2.4 $\underline{30}$

Martha, F. (2010). Naskah Skenarion "Kadek Made in Bali". Jakarta: RCTI.

Maryani, E., Rahmawan, D., Garnesia, I., \& Ratmita, R. (2020). Management and Psychological Aspect: Teenagers' Awareness of Privacy in Social Media. Jurnal Komunikasi Ikatan Sarjana Komunikasi Indonesia, 5(2), 168-178.

doi:https://doi.org/10.25008/jkiski.v5i2. $\underline{429}$

Novak M. (1991). Television Shapes the Soul. In J. Hanson \& A. Alexander (Eds.), Taking sides: Clashing Views on Controversial Issues in Mass Media and society. Guilford, CT: Dushkin Publishing Group.

Prasiasa, D.P.O. (2013). Destinasi Pariwisata Berbasis Masyarakat. Jakarta: Salemba Humanika. 
Riyaldi, S. (2001). Interaksionisme Simbolik (Perspektif Sosiologi Modern). Malang: Averroes Press.

Slavin. (2000). Educational Psychology: Theory and Practice. Sixth Edition. Boston: Allyn and Bacon.

Sobur, A, 2001. Analisis Teks Media. Bandung: Remaja Rosda Karya.

Sugihastuti, S. (2005). Kritik Sastra Feminis: Teori dan Aplikasinya. Yogyakarta: Pustaka Pelajar.

Sujarwa. (2010). Mitos Dibalik Kisah-kisah Sinetron Dalam Perpektif: Hegemoni dan Kapitalisasi. Yogyakarta: Pustaka Pelajar.

Zainal, A., Wijaya, T., \& Wardhani, A. (2021). Communication Strategy of Relationship Chat Account Manager in Managing the Follower. Jurnal Komunikasi Ikatan Sarjana Komunikasi Indonesia, 6(1), 3243.

doi:https://doi.org/10.25008/jkiski.v6il. $\underline{363}$ 